\title{
The Cultivable Microbiota Associated with Four Antarctic Macroalgae
}

\author{
Barreto CC1*, Duarte RTD², Lima DV3, de Oliveira Filho EC4, Absher \\ $\mathrm{TM}^{5}$ and Pellizari $\mathrm{VH}^{3}$ \\ 1Universidade Católica de Brasília, Programa de Ciências Genômicas e Biotecnologia, \\ Brazil \\ ${ }^{2}$ Universidade Federal de Santa Catarina, Departamento de Microbiologia, Imunologia e \\ Parasitologia, Brazil \\ 3Universidade de São Paulo, Instituto de Ciências Biomédicas, Brazil \\ ${ }^{4}$ Universidade de São Paulo, Instituto de Biociências, Departamento de Botânica, Brazil \\ ${ }^{5}$ Universidade Federal do Paraná, Centro de Estudos do Mar, Brazil
}

Short Communication

Volume 2 Issue 2

Received Date: July 28, 2017

Published Date: August 03, 2017

DOI: $10.23880 /$ oajmb-16000122

*Corresponding author: Cristine Chaves Barreto, Universidade Católica de Brasília, Programa de Ciências Genômicas e Biotecnologia, Brasília - Brazil, Tel: 055613448 9217; E-mail: criscbarreto@gmail.com

\section{Abstract}

Marine macroalgae are suitable surfaces for bacterial colonization; in fact, this microbiota is important to the cycling of organic material from algal origin. We describe the cultivable microbiota associated with four endemic Antarctic macroalgae: Palmariadecipiens, Himantothallus grandifolius, Desmarestia antarctica, and Ascoseira mirabilis. Among the bacterial colonies obtained on marine agar $71.4 \%$ were affiliated to Proteobacteria, $20 \%$ to Firmicutes, and $8.6 \%$ to Bacteroidetes. Pseudoalteromonas was the only genus present in all samples; otherwise, each macroalga presented a unique microbiota, which was distinct from macroalgae from northern oceans. These results indicated a species-specific interaction between Antarctic macroalgae and its surface microbiota.

Keywords: Antarctic Seaweed; Antarctic Macroalgae; Seaweed Microbiota; Macroalgae Microbiota

\section{Introduction}

The microbial community associated to macroalgae (seaweed) is diverse and complex, differing among algal phyla and species, season, and host age [1]. Interactions between marine macroalgae and microorganisms are very diverse as well; macroalgae provides home and nutrients, a resultant from algal photosynthesis, to associated microorganisms [2]. On the other hand, it was demonstrated that bacteria influence algal growth by producing vitamins [3] or even increasing bio-availability of $\mathrm{Fe}$ [4]. Another example is the highly specific association between Vibrio angularum and the green macroalga Ulva in which algal zoospores will only establish on a surface in the presence of certain chemical signals from their bacterial partner [5]. Some authors also reported the essential role of specific bacterial communities for the normal development of the algal host $[6,7]$. Such intimate association suggests that macroalgae 


\section{Open Access Journal of Microbiology \& Biotechnology}

and bacteria interact as a unified functional entity or holobiont [8].

There are few studies on the ecological aspects of the interactions between macroalgae and its microbiota. The majority of the studies describe the bacteria associated with edible macroalgae, especially Pyropia, Laminaria and Undaria that are consumed in Japan, Korea and China as well as Palmariapalmata which is consumed in Ireland. Such studies were directed to identify one algal or human pathogen on themacroalgae $[9,10]$. The prevalence of the family Flavobacteriaceae was reported previously in studies on the macroalgae from the Gulf of Peter the Great (Sea of Japan) [11-13].

The importance of the macroalgae and their associated microbiota to the carbon cycle in Antarctic oceans may be underestimated.Scientific studies revealed the presence of many species of microorganisms in Polar environments unveiling the important role of Antarctic bacteria in consuming, producing, and sequestering different kinds of compounds. Although macroalgae are abundant in the Antarctic Peninsula, little is known about the diversity of the microbiota associated with macroalgae from cold environments, especially from species endemic to polar environments.

An undergoing research developed in the surroundings of the Brazilian Antarctic Scientific Station - Comandante Ferraz (EACF) showed that the Rhodophyte Palmariadecipiens is the most common macroalga in the Antarctic Peninsula [14]. The estimated biomass produced by deposition of macroalgae casted ashore on the beach of EACF is about $60 \mathrm{~kg}$ by lineal meter of shore, with $P$. decipiens comprising up to $95 \%$ of this biomass.The objective of the present work was to survey the bacterial species that inhabit the surface of macroalgae by isolating and characterizing heterotrophic bacteria associated with four common species of marine Antarctic macroalgae.

\section{Material and Methods}

Living individuals of four species of macroalgae were collected in Admiralty Bay, King George Island, in February of 2007. Samples of Ascoseira mirabilis and Himantothallus grandifolius were collected in Demay Point; Desmarestia antarctica in Agat Point; and Palmariadecipiens from areas close to the Brazilian station [14].

Each alga was washed three times in sterile distilled water to remove bacteria that were loosely associated; 10 $\mathrm{g}$ of each alga were grinded in sterile seawater. A 100 -fold dilution of this mixture was inoculated on Marine Agar 2216 (DIFCO) and the plates were incubated at $10^{\circ} \mathrm{C}$ for 7 to 11 days. Bacterial colonies were selected based on morphological characteristics. Cell morphology was checked for purity and uniformity using bright field microscopy after a Gram staining.

DNA of each colony was extracted from $5 \mathrm{~mL}$ of liquid culture [15]. The gene for the 16S rRNA was amplified by PCR reaction using the Universal primers $27 \mathrm{~F}$ and $1401 \mathrm{R}$ $[16,17]$. The nearly-full sequences of the 16S rRNA gene were obainted using the same primers described above. The nucleotide sequences were analyzed using the software Bio Edit [18] and Bacterial affiliation was determined using the Ribosomal Database Project II [19]. Corresponding sequences were deposited in the GenBank under the numbers JQ618815-JQ618847.

Multivariate analyses were applied to summarize the data. A matrix containing the microbiota associated with macroalga species was generated and used for the Detrended Correlation Analysis (DCA), revealing the linear distribution of data (gradient size $<4.0$ ), which was further analyzed by Principal Component Analysis (PCA) [20]. The multivariate analyses were carried out using Canoco 4.5 [21].

\section{Results and Discussion}

Thirty three cultivable bacteria associated with Antarctic macroalgae were isolated. Seven isolates (21.2\%) were Gram-positive cocci and 26 (78.8\%) Gramnegative bacilli. The analysis of the 16S rRNA gene revealed that they belonged to three Bacterial phyla: Firmicutes, Bacteroidetes and Proteobacteria (Table 1)

Proteobacteria was the most abundant and diverse Bacterial phylum (71.4\%) found among the isolates; they were either affiliated with the Gamma Proteobacteria (Pseudoalteromonas, Halomonas, Cobetia, Marinomonas, Colwellia, Pseudomonas, and Psychrobacter) or to the Alpha Proteobacteria (Sulfitobacter). Phylum Firmicutes was the second most represented (20\%); the sequences were affiliated with the genera Aerococcus or Planococcus, representing the Gram positive bacteria initially observed. Only three bacteria were affiliated with the Phylum Bacteroidetes (8.6\%), these bacteria were related to the genera Maribacter, Polaribacter, and Winograskyella (Table 1). Previous studies revealed that these phyla are common in polar marine environments such as: sea ice [22], seawater [23], and macroalga from the Gulf of Peter the Great $[11,13]$. 
Although some of the genera were already observed in association with marine macroalgae from northern oceans, the composition of their microbiota is distinct from the Antarctic macroalgae [11,24]. In addition, the genera Aerococcus, Polaribacter, Winogradskyella, and Colwellia were for the first time observed on such surfaces. It is possible that the differences observed on cultivable microbiota from Antarctic and non-Antarctic macroalgae may be due to differences in culture media or cultivation techniques, since the choice of culture medium favors the growth of specific genera.

The genus Pseudoalteromonas was observed in all four Antarctic macroalgae; over $61.5 \%$ of the isolates associated with $A$. mirabilis belonged to this bacterial genus. Except for the genus Pseudoalteromonas, each macroalgae species studied presented a distinct bacterial composition, which was further validated statistically by PCA; that showed differences in the microbiota of the four macroalgae species analyzed (Figure 1). This result suggests a species-specific association between macroalga and microbiota. This observation is in agreement with previous studies comparing the cultivable microbiota, which indicated a species-specific microbial community on non-Antarctic algal species from the Sea of Japan [11] and Tuandao Bay, China [24].

Although molecular analysis applied on the metagenome may provide a better representation of the microbial richness from an environmental sample, it is not free from technical biases [25]. One advantage of classic culture techniques is the possibility of further studies on interactions between organisms and the screening of novel bacterial products for biotechnological applications [1]. Therefore, the present study provided not only information about the cultivable heterotrophic bacteria on Antarctic algal surfaces, but also allows for further investigation on the nature of this interaction.

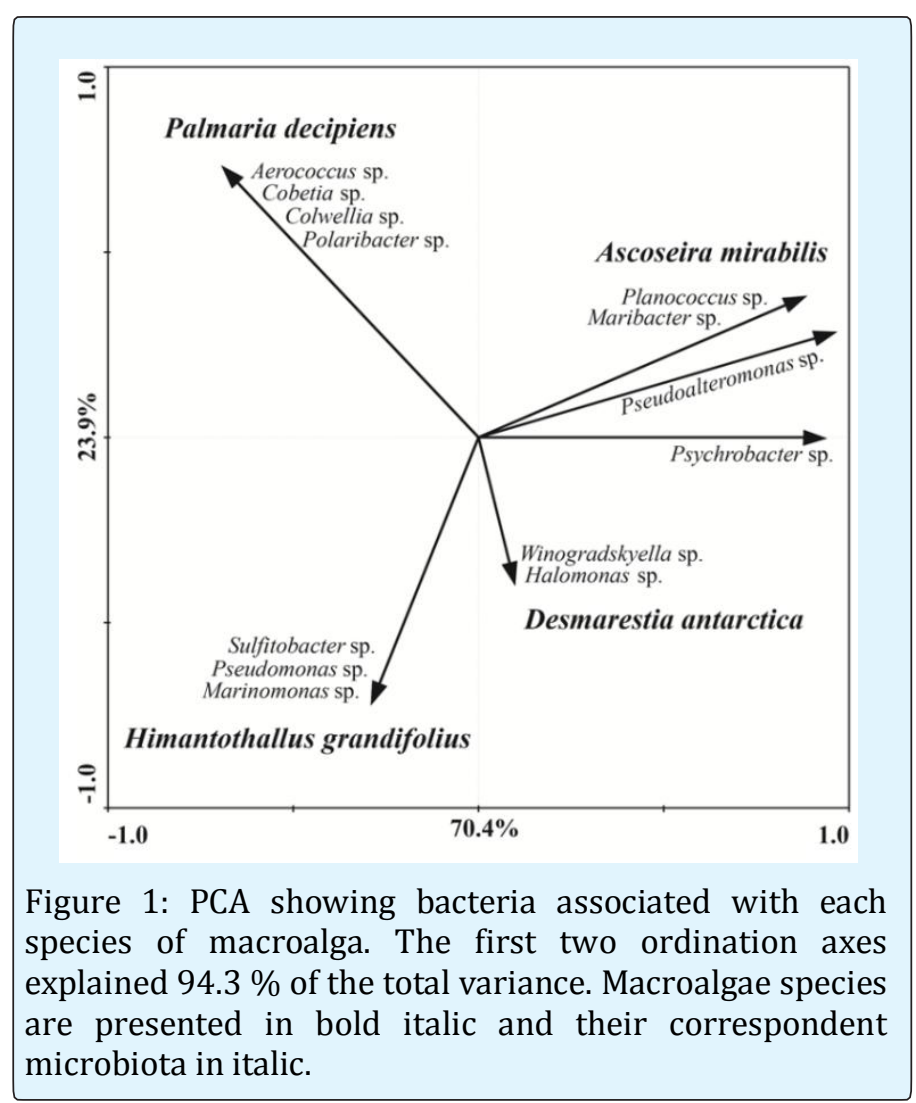

\begin{tabular}{|c|c|c|c|}
\hline Colony Identification & Division Affiliation & $\begin{array}{c}\text { Nearest phylogenetic relative in } \\
\text { Genebank }\end{array}$ & Identity \\
\hline EACF-12a[Am] & Bacteroidetes & Maribacterarcticus(AY771762) & 0.94 \\
\hline EACF-1 ${ }^{[\mathrm{Pd}]}$ & Bacteroidetes & Polaribacter sp. SW007 (F493674) & 0.94 \\
\hline EACF-26a ${ }^{[\mathrm{Da}]}$ & Bacteroidetes & $\begin{array}{c}\text { Winogradskyellathalassocola; S4-7 } \\
\text { (Y771731) }\end{array}$ & 0.92 \\
\hline $\begin{array}{c}\text { EACF-2[Pd]; EACF-4[Pd]; EACF-6[Pd]; EACF-7[Pd]; } \\
\text { EACF-27a }{ }^{[\mathrm{Pd}]}\end{array}$ & Firmicutes & Aerococcusviridans; 15MS (U075039) & 0.98 \\
\hline EACF-13a[Am];EACF-14a[Am] & Firmicutes & Planococcus sp. Nj-73 (M491471) & 0.96 \\
\hline EACF-21b ${ }^{[\mathrm{Hg}]}$ & $\begin{array}{c}\text { Proteobacteria } \\
\text { (Alpha) }\end{array}$ & Sulfitobacter sp. ARCTIC-P49 (Y573043) & 0.97 \\
\hline EACF-27b ${ }^{[\mathrm{Pd}]}$ & $\begin{array}{c}\text { Proteobacteria } \\
\text { (Gamma) }\end{array}$ & Cobetia sp. 191Z-6 (JX310224) & 0.98 \\
\hline
\end{tabular}




\section{Open Access Journal of Microbiology \& Biotechnology}

\begin{tabular}{|c|c|c|c|}
\hline EACF-25b ${ }^{[D a]}$ & $\begin{array}{l}\text { Proteobacteria } \\
\text { (Gamma) }\end{array}$ & Halomonas sp. NT N45 (B166987) & 0.99 \\
\hline $\mathrm{EACF}-3[\mathrm{Pd}]$ & $\begin{array}{l}\text { Proteobacteria } \\
\text { (Gamma) }\end{array}$ & Colwellia sp. IE7-5 (Y829231) & 0.96 \\
\hline EACF-19[Hg] & $\begin{array}{l}\text { Proteobacteria } \\
\text { (Gamma) }\end{array}$ & Marinomonas sp. BJK17 (J717295) & 0.96 \\
\hline EACF-20[Hg] & $\begin{array}{l}\text { Proteobacteria } \\
\text { (Gamma) }\end{array}$ & Pseudomonas sp. ARCTIC-P33 (Y573033) & 0.97 \\
\hline EACF-17a ${ }^{[\mathrm{Am}]}, \mathrm{EACF}-23^{[\mathrm{Da}]}, \mathrm{EACF}-25 \mathrm{a}^{[\mathrm{Da}]}$ & $\begin{array}{l}\text { Proteobacteria } \\
\quad \text { (Gamma) }\end{array}$ & Psychrobacter sp. St1 (F260715) & 0.97 \\
\hline EACF-18[Am] & $\begin{array}{l}\text { Proteobacteria } \\
\text { (Gamma) }\end{array}$ & $\begin{array}{c}\text { Psychrobacterglacincola; NT9276b } \\
\text { (Y167310) }\end{array}$ & 0.98 \\
\hline EACF-15a ${ }^{[\mathrm{Am}]} ; \mathrm{EACF}-22 \mathrm{a}^{[\mathrm{Da}]} ; \mathrm{EACF}-28^{[\mathrm{Pd}]}$ & $\begin{array}{l}\text { Proteobacteria } \\
\text { (Gamma) }\end{array}$ & \begin{tabular}{|c|}
$\begin{array}{c}\text { Pseudoaltero monashaloplanktis TAC125 } \\
\text { (CR954246) }\end{array}$ \\
\end{tabular} & 0.97 \\
\hline EACF-11[Am] & $\begin{array}{l}\text { Proteobacteria } \\
\text { (Gamma) }\end{array}$ & $\begin{array}{c}\text { Pseudoalteromonas sp. BSw20001 } \\
\text { (U365590) }\end{array}$ & 0.98 \\
\hline EACF-12b ${ }^{[\mathrm{Am}]}$ & $\begin{array}{l}\text { Proteobacteria } \\
\text { (Gamma) }\end{array}$ & Pseudoalteromonas sp. SUR560 (B038036) & 0.99 \\
\hline $\begin{array}{c}\text { EACF-13b }{ }^{[\mathrm{Am}]} ; \text { EACF-15b }^{[\mathrm{Am}]} ; \text { EACF-16[Am] } \\
\text { EACF-26b }\end{array}$ & $\begin{array}{l}\text { Proteobacteria } \\
\text { (Gamma) }\end{array}$ & $\begin{array}{l}\text { Pseudoalteromonas sp. WINTA324h } \\
\text { (B274777) }\end{array}$ & 0.99 \\
\hline EACF-17b[Am]; EACF-21a ${ }^{[\mathrm{Hg}]} ; \mathrm{EACF}-24 \mathrm{~b}^{[\mathrm{Da}]}$ & $\begin{array}{l}\text { Proteobacteria } \\
\quad \text { (Gamma) }\end{array}$ & Pseudoalteromonas sp.; IC006 (U85856) & 0.98 \\
\hline EACF-14b[Am] & $\begin{array}{l}\text { Proteobacteria } \\
\text { (Gamma) }\end{array}$ & $\begin{array}{l}\text { Pseudoalteromonas sp. WINTA44d } \\
\text { (B274773) }\end{array}$ & 0.99 \\
\hline
\end{tabular}

Table 1: Affiliation of the isolated bacteria associated with macroalga according to the 16S rRNA gene phylogeny.

Letters inside brackets indicate the macroalga from which this bacterium was obtained: Am: Ascoseira mirabilis, Hg: Himantothallusgr andifolius, Da: Desmarestia antarctica, and Pd: Palmariadecipiens

\section{Acknowledgements}

This research was funded by the Brazilian National Counsel of Technological and Scientific Development CNPq. Rubens T. D. Duarte received scholarship from Fundação de AmparoàPesquisa do Estado de São Paulo (FAPESP - grant \#2012/11037-0). This study was made possible with the logistic support from the Brazilian Antarctic Programme (PROANTAR). It was included in the API activity 403 "MIDIAPI Microbial Diversity of Terrestrial and Maritime ecosystems in Antarctic Peninsula" under the 2007-2008 International Polar Year activities of Projects MERGE (Microbiological and Ecological Responses to Global Environmental Changes in Polar Regions), CAML (Census of Antarctic Marine Life), and SCAR MarBIN (SCAR-Marine Biodiversity Information Network). We thank Dr. Fernando Dini Andreote and Dr. Ederson da Conceição Jesus for the statistical support.

\section{References}

1. Martin M, Daniel P, Gurvan M, Micheline V (2014) Microorganisms living on macroalgae: diversity, interactions, and biotechnological applications. Appl Microbiol Biotechnol 98(7): 2917-2935.

2. Armstrong E, Yan LM, Boyd KG, Wright PC, Burgess JG (2001) The symbiotic role of marine microbes on living surfaces. Hydrobiologia 461(1-3): 37-40.

3. Croft MT, Warren MJ, Smith AG (2006) Algae need their vitamins. Eukaryot Cell 5(8): 1175-1183.

4. Keshtacherliebson E, Hadar Y, Chen Y (1995) Oligotrophic bacteria enhance algal growth under iron-deficient conditions. Appl Environm Microbiol 61(6): 2439-2441. 


\section{Open Access Journal of Microbiology \& Biotechnology}

5. Joint I, Tait K, Wheeler G (2007) Cross-kingdom signalling: exploitation of bacterial quorum sensing molecules by the green seaweed Ulva. PhilosTrans R Soc Lond B Biol Sci 362(1483): 1223-1233.

6. Matsuo Y, Imagawa H, Nishizawa M, Shizuri Y (2005) Isolation of an algal morphogenesis inducer from a marine bacterium. Science 307(5715): 1598.

7. Singh R, Mantri V, Reddy C, Jha B (2011) Isolation of seaweed-associated bacteria and their morphogenesisinducing capability in axenic cultures of the green alga Ulva fasciata. Aquat Biol 12(1): 1321.

8. Egan S, Harder T, Burke C, Steinberg P, Kjelleberg S, et al. (2013) The seaweed holobiont: understanding seaweed-bacteria interactions. FEMS Microbiol Rev 37(3): 462-476.

9. Moore JE, Xu J, Millar BC (2002) Diversity of the microflora of edible macroalga (Palmaria palmata). Food Microbiol 19(2-3): 249-257.

10. Vairappan CS, Suzuki M, Motomura T, Ichimura T (2001) Pathogenic bacteria associated with lesions and thallus bleaching symptoms in the Japanese kelp Laminaria religiosa Miyabe (Laminariales, Phaeophyceae). Hydrobiologia 445(4-5): 183-191.

11. Beleneva IA, Zhukova NV (2006) Bacterial communities of brown and red algae from Peter the Great Bay, the Sea of Japan. Mikrobiologiia 75(3): 410-419.

12. Ivanova EP, Christen R, Alexeeva YV, Zhukova NV, Gorshkova NM, et al. (2004) Brevibacterium celere sp nov., isolated from degraded thallus of a brown alga. Int J Syst Evol Microbiol 54(6): 2107-2111.

13. Nedashkovskaya OI, Kim SB, Han SK, Snauwaert C, Vancanneyt M, et al. (2005) Winogradskyella thalassocola gen. nov., sp nov., Winogradskyella epiphytica sp nov and Winogradskyella eximia sp nov., marine bacteria of the family Flavobactefiaceae. Int J Syst Evol Microbiol 55(1): 49-55.

14. Oliveira EC, Absher TM, Pellizzari FM, Oliveira MC (2009) The seaweed flora of Admiralty Bay, King George Island, Antarctic. Polar Biol 32(11): 16391647.
15. Wilson K (1989) Preparation of genomic DNA from bacteria. In: Ausubel FM, Brent R, Kingston R et al. (eds), Current Protocols in Molecular Biology. Wiley, John \& Sons, Inc., New York.

16. Lane DJ (1991) 16S/23S rRNA sequencing. In: E Stackebrandt and M Goodfellow (eds), Nucleic acid techniques in bacterial systematics. John Wiley \& Sons, New York, pp: 115-175.

17. Nübel U, Engelen B, Felske A, Snaidr J, Wieshuber A, et al. (1996) Sequence heterogeneities of genes encoding 16S rRNAs in Paenibacillus polymixa detected by temperature gradient gel electrophoresis. J Bacteriol 178(19): 5636-5643.

18. Hall TA (1999) BioEdit: a user-friendly biological sequence alignment editor and analysis program for Windows 95/98/NT. Nucleic Acids Symposium Series 41: 95-98.

19. Cole JR, Chai B, Marsh TL, Farris RJ, Wang Q, et al. (2003) The Ribosomal Database Project (RDP-II): previewing a new autoaligner that allows regular updates and the new prokaryotic taxonomy. Nucleic Acids Res 31(1): 442-443.

20. Ramette A (2007) Multivariate analyses in microbial ecology. FEMS Microbiol Ecol 62(2): 142-160.

21. Braak CJFT, Smilauer P (2002) CANOCO Reference Manual and CanoDraw for Windows User's Guide: Software for Canonical Community Ordination (version 4.5). Microcomputer Power, Ithaca NY, USA.

22. Bowman JP, McCammon SA, Brown MV, Nichols DS, McMeekin TA (1997) Diversity and association of psychrophilic bacteria in Antarctic sea ice. Appl Environm Microbiol 63(8): 3068-3078.

23. Mock T, Thomas DN (2005) Recent advances in seaice microbiology. Environm Microbiol 7(5): 605-619.

24. Wang Z, Xiao T, Pang S, Liu M, Yue H (2009) Isolation and identification of bacteria associated with the surfaces of several algal species. Chinese Journal of Oceanology and Limnology 27(3): 487-492.

25. Lombard N, Prestat E, Van Elsas JD, Simonet P (2011) Soil-specific limitations for access and analysis of soil microbial communities by metagenomics. FEMS Microbiology Ecology 78(1): 31-49. 


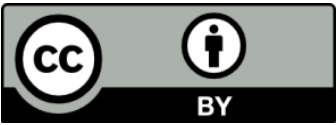

